\title{
Kinga Cecylia Stasiak (1981-2019)
}

Kinga Cecylia Stasiak urodziła się 16 lutego 1981 r. w Lublinie. Uczęszczała do Szkoły Podstawowej nr 14 im. Tadeusza Kościuszki w Lublinie, a następnie do renomowanej lubelskiej szkoły średniej - III Liceum Ogólnokształcącego im. Unii Lubelskiej, w którym złożyła z sukcesem egzamin maturalny w $2000 \mathrm{r}$. W tym samym roku rozpoczęła studia prawnicze na Wydziale Prawa, Prawa Kanonicznego i Administracji Katolickiego Uniwersytetu Lubelskiego, z którym - jak się później okazało - związała całe swoje życie zawodowe. W trakcie studiów uczestniczyła w wielu kursach Szkoły Prawa Amerykańskiego KUL, a ponadto w 2002 i 2003 r. w Szkole Letniej Centrum Prawa Amerykańskiego - The Summer School of Human Rights and European Law (we współpracy z Catholic University of Leuven). Brała też udział w 2003 i w 2004 r. w Philip C. Jessup International Law Moot Court Competition. W latach 2003-2005 uczęszczała na zajęcia Centrum Prawa Amerykańskiego KUL, prowadzone we współpracy w Chicago-Kent College of Law, które ukończyła z wyróżnieniem ${ }^{1}$.

W 2005 r. przedłożyła pracę magisterską pt. Interwencja humanitar$n a$ w świetle prawa międzynarodowego, przygotowaną pod kierunkiem dr hab. Anny Przyborowskiej-Klimczak. Na podstawie tejże pracy i złożonego

* Prof. dr hab., Katedra Postępowania Cywilnego, Wydział Prawa, Prawa Kanonicznego i Administracji, Katolicki Uniwersytet Lubelski Jana Pawła II, e-mail: joanna.misztal-konecka@kul.pl, https:// orcid.org/0000-0001-8849-5447.

1 Akta w Archiwum Uniwersyteckim KUL nr 76322 oraz A-4504; s.v. Stasiak Kinga, w: Encyklopedia 100-lecia KUL, t. 2, red. E. Gigilewicz, Lublin 2018, s. 372-373; W.Sz. Staszewski, A. Szarek-Zwijacz, In memoriam. Kinga Cecylia Stasiak 1981-2019, Studia Prawnicze 2019, nr 2, s. 7. 
egzaminu magisterskiego uzyskała tytuł zawodowy magistra prawa. Studia prawnicze ukończyła z oceną bardzo dobrą ${ }^{2}$.

Zmierzając do rozwijania zamiłowań badawczych w zakresie prawa międzynarodowego publicznego, niezwłocznie po zakończeniu studiów magisterskich rozpoczęła studia doktoranckie pod kierunkiem dr hab. Anny Przyborowskiej-Klimczak. Od 1 października 2006 r. została zatrudniona na stanowisku asystenta w Katedrze Prawa Międzynarodowego Publicznego, od 2009 r. zaś w Katedrze Prawa Międzynarodowego i Amerykańskiego Wydziału Prawa, Prawa Kanonicznego i Administracji KUL. W 2008 r. otrzymała stypendium od Grotius Centre for International Legal Studies, które umożliwiło jej udział w zajęciach szkoły letniej dla doktorantów Marie Curie Top Summer School, odbywającej się w Hadze w dniach 30 czerwca - 11 lipca 2008 r. (Summer School on International Criminal Law). Przeprowadziła kwerendy naukowe w bibliotece Vredespaleis (Pałacu Pokoju) w Hadze (26 sierpnia - 6 września 2008, 22-30 sierpnia 2011, 10-13 września 2012) oraz w Europe's Research Institute we Florencji (7-15 lipca 2013). Pobyty te wykorzystała także, by obserwować prace Międzynarodowego Trybunału dla b. Jugosławii (30 czerwca - 11 lipca 2008) oraz Międzynarodowego Trybunału Karnego (30 czerwca - 11 lipca 2008, 22-30 sierpnia 2011, 10-13 września 2012).

Sprawnie prowadzone prace badawcze zaowocowały przygotowaniem i świetną obroną rozprawy doktorskiej pt. Umiędzynarodowione trybunaty karne w systemie międzynarodowego sądownictwa karnego $\mathrm{w}$ dniu 19 października 2010 r. na Wydziale Prawa, Prawa Kanonicznego i Administracji KUL. Promotorem rozprawy była dr hab. Anna Przyborowska-Klimczak, prof. UMCS, a recenzentami dr hab. Barbara Mikołajczyk, prof. UŚ, z Uniwersytetu Śląskiego i dr hab. Krzysztof Wiak (KUL). Recenzenci niezwykle wysoko ocenili wybór tematu dysertacji doktorskiej, jak również próbę udzielenia odpowiedzi na pytanie, czy ukształtował się jednolity model trybunałów umiędzynarodowionych, a także określenia, jakie relacje łączą trybunały umiędzynarodowione $\mathrm{z}$ innymi trybunałami karnymi oraz jaki wkład wnoszą trybunały umiędzynarodowione na rzecz rozwoju międzynarodowego prawa karnego. W dniu

2 Akta w Archiwum Uniwersyteckim KUL nr 76322; s.v. Stasiak Kinga, w: Encyklopedia 100-lecia KUL..., s. 373; W.Sz. Staszewski, A. Szarek-Zwijacz, In memoriam..., s. 7. 
16 listopada 2010 r. Rada Wydziału podjęła uchwałę o nadaniu Kindze Cecylii Stasiak stopnia naukowego doktora nauk prawnych ${ }^{3}$.

Poczynając od dnia 1 października 2011 r., K. Stasiak pozostawała zatrudniona na stanowisku adiunkta w Katedrze Prawa Międzynarodowego i Amerykańskiego KUL. Dodatkowo prowadziła również zajęcia w Akademii Obrony Narodowej w Warszawie ${ }^{4}$.

W czasie zatrudnienia prowadziła prace badawcze, działalność dydaktyczną oraz z pasją poszerzała wiedzę i współpracę dzięki licznym wyjazdom zagranicznym. Poza wspomnianymi już uprzednio wyjazdami zagranicznymi, w okresie 7 stycznia - 6 kwietnia 2015 r. odbyła ona staż naukowy w Max Planck Institute for Comparative Public Law and International Law (Heidelberg) w ramach projektu "Najlepsze praktyki” w strategicznej transformacji KUL. W ramach Programu Erasmus+ w dniach 16-20 maja 2016 r. wykładała w Sulkhan-Saba Orbeliani Teaching University w Gruzji, prezentując zagadnienia związane z powstaniem i działalnością Międzynarodowego Trybunału Karnego, w tym: zakres jego jurysdykcji, przebieg postępowania oraz znaczenie międzynarodowe ${ }^{5}$.

Kinga Stasiak nigdy nie uchylała się od najtrudniejszych nawet prac organizacyjnych na rzecz Wydziału i Uniwersytetu, wśród których na szczególne podkreślenie zasługują m.in. pełnienie przez wiele lat funkcji sekretarza katedry, opiekuna praktyk studenckich oraz wydziałowego koordynatora Programu Erasmus, a następnie Erasmus+, jak też prace w komisji Krajowych Ram Kształcenia dla kierunku prawo i w Komisji Programowej Instytutu Prawa, a ponadto sprawowanie funkcji sekretarza czasopisma Review of Comparative Law (2012-2014) i redaktora tematycznego w Kolegium Redakcyjnym Studiów Prawniczych KUL (2016-2019) ${ }^{6}$. Jako instytutowy koordynator Programu Erasmus/Erasmus+ (do r. akad. 2017/18) realizowała największą liczbę mobilności spośród wszystkich koordynatorów na KUL, a jednocześnie uzyskiwała najwyższe oceny za swoją pracę wystawiane przez wyjeżdżających i przyjeżdżających uczestników (studentów i pracowników). Warto też

3 Akta w Archiwum Uniwersyteckim KUL nr 76322 oraz A-4504; W.Sz. Staszewski, A. Szarek-Zwijacz, In memoriam..., s. 8.

4 Akta w Archiwum Uniwersyteckim KUL nr A-4504; s.v. Stasiak Kinga, w: Encyklopedia 100-lecia KUL..., s. 373; W.Sz. Staszewski, A. Szarek-Zwijacz, In memoriam..., s. 8.

5 Tamże.

6 Tamże. 
wskazać, że ostatnim akordem jej dorobku była współredakcja tomu 2 publikacji Prawo międzynarodowe publiczne. Studia i Materiaty ${ }^{7}$.

Kinga Stasiak była członkiem International Law Association - Polish Branch, w którym przez dwie kadencje pełniła funkcję członka Komisji Rewizyjnej ${ }^{8}$.

W uznaniu jej zaangażowania Rektor KUL wyróżnił ją dwukrotnie nagrodą zespołową $(2009,2013)^{9}$.

Zmarła w Zamościu dnia 14 lutego 2019 r. po ciężkiej i wyczerpującej chorobie $^{10}$.

Odrębnego wskazania i podkreślenia wymaga zaangażowanie dydaktyczne K. Stasiak, dla której praca ze studentami nie była tylko wypełnieniem jednego z pracowniczych obowiązków. Nie ograniczyła się ona do prowadzenia zajęć $\mathrm{z}$ prawa międzynarodowego publicznego i powiązanych z nim przedmiotów, w języku polskim i angielskim, ale z pasją i przekonaniem propagowała tak poszerzanie aktywności studenckich, jak i umiejętności językowych, zwłaszcza w zakresie znajomości prawniczego języka angielskiego. Ze spektakularnymi efektami przygotowywała drużyny KUL do udziału w międzynarodowych konkursach prawniczych: Philip C. Jessup International Law Moot Court Competition, Manfred Lachs Space Law Moot Court Competition oraz Telders Moot Court Competition. Ponadto była współorganizatorem kilku edycji Legal Forum adresowanego do studentów, uczestniczących w lektoracie języka angielskiego o profilu prawniczym, w ramach którego zainteresowani prezentowali w tym języku wcześniej zaproponowane zagadnienia prawnicze.

7 Prawo międzynarodowe publiczne, red. K. Stasiak, W.Sz. Staszewski, A. Szarek-Zwijacz, Lublin 2019.

8 Akta w Archiwum Uniwersyteckim KUL nr A-4504; s.v. Stasiak Kinga, w: Encyklopedia 100-lecia KUL..., s. 373; W.Sz. Staszewski, A. Szarek-Zwijacz, In memoriam..., s. 8.

9 Akta w Archiwum Uniwersyteckim KUL nr A-4504; s.v. Stasiak Kinga, w: Encyklopedia 100-lecia KUL..., s. 373.

10 Akta w Archiwum Uniwersyteckim KUL nr A-4504. 
Natomiast międzyuczelniane konferencje prawnicze w języku angielskim, w które była szczególnie zaangażowana, od 2019 r. noszą jej imię ${ }^{11}$.

Kinga Stasiak prowadziła zróżnicowane zajęcia: ćwiczenia, wykłady, seminaria. Pod Jej pieczą przygotowano blisko sześćdziesiąt prac magisterskich na kierunku administracja (25) i na kierunku prawo (32) ${ }^{12}$.

Dorobek naukowy K. Stasiak - poza monografią Trybunaty umiędzynarodowione w systemie międzynarodowego sądownictwa karnego (Lublin 2012), obejmuje czternaście artykułów naukowych opublikowanych w czasopismach naukowych i pracach zbiorowych, pięć tłumaczeń tekstów źródłowych oraz trzy drobne wypowiedzi naukowe ${ }^{13}$. Nie można również nie wspomnieć o hasłach encyklopedycznych przygotowanych do Leksykonu obywatela ${ }^{14}$, Leksykonu prawa międzynarodowego publicznego.

11 s.v. Stasiak Kinga, w: Encyklopedia 100-lecia KUL..., s. 373; W.Sz. Staszewski, A. Szarek-Zwijacz, In memoriam..., s. 12. Zob. też VII Międzyuczelniana Konferencja Prawnicza imienia dr Kingi Stasiak - 21 maja 2019, https:/ / www.kul.pl/vii-mi-dzyuczelniana-konferencja-prawnicza-imienia-dr-kingi-stasiak-21-maja-2019,gal_17195.html [dostęp: 15.01.2020 r.].

12 s.v. Stasiak Kinga, w: Encyklopedia 100-lecia KUL..., s. 373; W.Sz. Staszewski, A. Szarek-Zwijacz, In memoriam..., s. 12.

${ }^{13} \mathrm{~W}$ tej grupie wskazać należy wspomnienie o ks. prof. Antonim Kościu (J. Potrzeszcz, K. Stasiak, Mortui vivos docent. In Memory of Rev. Prof. Antoni Kość, SVD, Review of Comparative Law 2012, t. 17, s. 11-17), recenzję (K. Stasiak, [rec.:] Robert Grzeszczak, Parlamenty państw członkowskich w Unii Europejskiej, Wydawnictwo Uniwersytetu Wrocławskiego, Wrocław 2004, ss. 256, Studia Prawnicze KUL 2007, nr 1, s. 205-208) i sprawozdanie (K. Stasiak, Icty Prosecutor Serge Brammertz, International Criminal Justice: Lessons Learned, Future Challenges Supranational Criminal Law Lecture Series. Haga, 12 września 2012 r., Studia Prawnicze KUL 2013, nr 1, s. 201-204).

14 Leksykon obywatela, red. S. Serafin, B. Szulik, wstęp J. Kochanowski, Warszawa 2008; autorstwo haseł: Agresja, s. 1109, Cieśniny międzynarodowe, s. 1113-1114, Cudzoziemcy, s. 1114-1115, Interwencja humanitarna, s. 1117-1118, Jeńcy wojenni, s. 1118, Kanały międzynarodowe, s. 1118-1119, Komisje badawcze, s. 1120, Koncyliacja, s. 1120, Konflikt zbrojny, s. 1121, Liga Państw Arabskich, s. 1122, Mediacje, s. 1122-1123, Międzynarodowe prawo humanitarne, s. 1123, Naturalizacja, s. 1127-1128, Obywatelstwo, s. 1128, Organizacja Państw Amerykańskich, s. 1134-1135, Przestrzeń kosmiczna, s. 1139-1140, Przestrzeń powietrzna, s. 1140, Repatriacja, s. 1142-1143, Rozbrojenie, s. 1144, Statek powietrzny, s. 1147, Unia Afrykańska, s. 1153, Zbrodnie międzynarodowe, s. 1156. 
100 podstawowych pojęć ${ }^{15}$, Leksykonu administratywisty ${ }^{16}$ oraz Encyklopedii Katolickiej ${ }^{17}$.

Już pobieżna analiza dorobku naukowego K. Stasiak wskazuje, że jest on znaczący nie tylko pod względem ilościowym, lecz także jakościowym, stanowiąc istotny element rozwoju prawa międzynarodowego publicznego. Nie można nie podkreślić wysokiej kultury słowa, niezwykle precyzyjnego posługiwania się językiem prawniczym oraz odpowiedzialności za formułowane tezy. Niezależnie od charakteru publikacji widoczne było stałe i pełne przekonania dążenie, by każda teza została udowodniona, by każdy detal został dopracowany. Tak ukształtowany standard pracy naukowej pozostanie wzorem trudnym do osiągnięcia dla wszystkich, którzy z jej pracami się stykali.

O dojrzałości K. Stasiak i jej sprecyzowanej wizji działalności naukowej świadczy pierwsza publikacja, stanowiąca kwintesencję analiz przeprowadzonych przy okazji przygotowania pracy magisterskiej. W artykule Warunki dopuszczalności interwencji humanitarnej ${ }^{18}$ przedstawiła pojęcie interwencji humanitarnej oraz sformułowane $\mathrm{w}$ regulacjach prawa międzynarodowego i poglądach przedstawicieli doktryny przesłanki podjęcia takiej interwencji, zwróciła też uwagę na sześć kryteriów upoważniających do podjęcia interwencji międzynarodowej (progowe kryterium słusznej sprawy, właściwe intencje, działanie w ostateczności, proporcjonalność środków, rozsądne perspektywy powodzenia oraz właściwe upoważnienie).

15 Leksykon prawa międzynarodowego publicznego. 100 podstawowych pojęć, red. A. Przyborowska-Klimczak, D. Pyć, Warszawa 2012; autorstwo haseł: Agresja, s. 5-12, Azyl, s. 23-28, Bezpieczeństwo międzynarodowe, s. 29-34, Dyskryminacja, s. 51-58, Jurysdykcja, s. 99-106, Okupacja, s. 282-290, Operacje pokojowe, s. 290-297, Prawo narodów do samostanowienia, s. 370-376, Rozbrojenie i ograniczenie zbrojeń, s. 408-413, Odszkodowania wojenne, s. 273-282 (współautor A. Szarek).

16 Leksykon administratywisty, red. S. Wrzosek, A. Haładyj, M. Domagała, Radom 2013; autorstwo haseł: Cudzoziemiec, s. 57-60, Konflikt zbrojny, s. 148-150, Mniejszości narodowe, s. 181-184, Odpowiedzialność międzynarodowa, s. 202-205, Przestrzeń powietrzna i kosmiczna, s. 362-364, Uchodźca, s. 494-497.

17 Encyklopedia Katolicka, t. 12, red. E. Ziemann, Lublin 2008; autorstwo haseł: Mniejszości narodowe. 2. Aspekt prawny, kol. 1452-1454, Mniejszości religijne. 2. Aspekt prawny, kol. 1456-1457.

18 K. Stasiak, Warunki dopuszczalności interwencji humanitarnej, w: Prawo międzynarodowe publiczne, red. A. Przyborowska-Klimczak, W.Sz. Staszewski, Lublin 2006, s. 109-128. 
Podstawowym obszarem poszukiwań naukowych K. Stasiak były zagadnienia międzynarodowego prawa karnego, ze szczególnym uwzględnieniem norm prawa międzynarodowego określających materialnoprawne i proceduralne aspekty odpowiedzialności za zbrodnie wojenne, przeciwko pokojowi i przeciwko ludzkości. Już w opublikowanym w 2007 r. artykule Specjalne Panele Sędziów w Timorze Wschodnim - jako przykład trybunału umiędzynarodowionego ${ }^{19}$ przedstawiła instytucję tytułowych Paneli funkcjonujących w Timorze Wschodnim w latach 2000-2005 w celu ukarania osób odpowiedzialnych za naruszanie podstawowych praw człowieka i prawa humanitarnego na tym obszarze (za popełnione w dowolnym czasie zbrodnie przeciwko ludności, ludobójstwa, zbrodnie wojenne, tortury, jak też popełnione od 1 stycznia do 25 października 1999 r. morderstwa i przestępstwa na tle seksualnym). Podsumowanie badań dotyczących wymierzania sprawiedliwości na gruncie międzynarodowej odpowiedzialności państw i osób fizycznych miała stanowić publikacja Trybunaty umiędzynarodowione w systemie międzynarodowego sądownictwa karnego ${ }^{20}$, która została oparta na obronionej w 2010 r. dysertacji doktorskiej. W pracy tej K. Stasiak podjęła analizę ustanowienia i funkcjonowania takich sądów jak Specjalny Trybunał dla Sierra Leone, Specjalny Trybunał dla Libanu, Nadzwyczajne Izby w Sądach Kambodżańskich, Specjalne Panele w Timorze Wschodnim, Panele umiędzynarodowione w Kosowie oraz Izba ds. Zbrodni Wojennych w Bośni i Hercegowinie. Analiza ta pozwoliła jej na wniosek, że trybunały umiędzynarodowione, mimo nieukształtowanego modelu, mogą stać się w przyszłości organami umożliwiającymi sądzenie sprawców poważnych zbrodni, z poszanowaniem zasad międzynarodowego prawa karnego i krajowych gwarancji procesowych w wypadku spraw niepodlegających jurysdykcji Międzynarodowego Trybunału Karnego. Podkreśliła przy tym, że jedynym elementem rzeczywiście wspólnym dla wszystkich trybunałów umiędzynarodowionych jest udział w ich składach sędziowskich i urzędzie prokuratorskim sędziów i prokuratorów międzynarodowych i krajowych ${ }^{21}$.

19 K. Stasiak, Specjalne Panele Sędziów w Timorze Wschodnim - jako przykład trybunału umiędzynarodowionego, w: Prawo międzynarodowe. Księga pamiatkowa profesor Renaty Szafarz, red. J. Menkes, Warszawa 2007, s. 518-535.

${ }^{20}$ K. Stasiak, Trybunaty umiędzynarodowione w systemie międzynarodowego sądownictwa karnego, Lublin 2012.

${ }^{21}$ Recenzję tej pracy opublikowała D. Kuźniar-Kwiatek, Studia Prawnicze KUL 2013, nr 1, s. 191-198. 
Po ukończeniu analiz statusu trybunałów umiędzynarodowionych K. Stasiak zwróciła się ku badaniom działalności Międzynarodowego Trybunału Karnego w Hadze. Dzięki odbytej w 2011 r. kwerendzie naukowej w Pałacu Pokoju w Hadze i obserwacji prac Międzynarodowego Trybunału Karnego powstał artykuł Wystapienia końcowe w sprawie Thomasa Lubangi Dyilo przed Międzynarodowym Trybunałem Karnym (25-26 sierpnia 2011 r., Haga 22, prezentujący szczegółowo nie tylko przedmiot tytułowych wystąpień, lecz także postawione oskarżonemu zarzuty oraz wyrok skazujący za popełnienie zbrodni wojennych w postaci wcielania lub werbowania dzieci poniżej piętnastego roku życia do narodowych sił zbrojnych lub faktycznego ich używania w działaniach zbrojnych. Kolejne prace dotyczące Międzynarodowego Trybunału Karnego K. Stasiak poświęciła aspektom proceduralnym jego działalności z punktu widzenia obrony ${ }^{23}$ i oskarżenia ${ }^{24}$. W tym samym nurcie sytuują się badania nad naprawieniem krzywd wyrządzonych ofiarom zbrodni międzynarodowych ${ }^{25}$. Wspomnieć również należy o artykule Prace Komisji Prawa Międzynarodowego nad zbrodniami przeciwko ludzkości a możliwe implikacje dla odpowiedzialności karnej jednoste ${ }^{26}$, w którym opowiedziała się stanowczo za potrzebą stworzenia powszechnie akceptowanej definicji zbrodni przeciwko ludzkości oraz współpracą horyzontalną państw-stron Statutu Międzynarodowego Trybunału Karnego.

22 K. Stasiak, Wystapienia końcowe w sprawie Thomasa Lubangi Dyilo przed Międzynarodowym Trybunałem Karnym (25-26 sierpnia 2011 r., Haga), Studia Prawnicze KUL 2012, nr 1, s. $115-125$.

${ }^{23}$ K. Stasiak, The Position of Defence Counsel before the International Criminal Court a Few Comments on the Lubanga Case, Review of Comparative Law 2012, t. 17, s. 85-108.

${ }^{24}$ K. Stasiak, Wspótpraca Organizacji Narodów Zjednoczonych z Prokuratorem Międzynarodowego Trybunatu Karnego, w: Prawo organizacji międzynarodowych wobec problemów wspótczesnego świata. Księga Jubileuszowa dedykowana Pani Profesor Genowefie Grabowskiej, red. B. Mikołajczyk, J. Nowakowska-Małusecka, Bydgoszcz-Katowice 2014, s. 323-333.

25 K. Stasiak, Zasady dotyczace naprawienia szkody pokrzywdzonym w postęowaniu przed Międzynarodowym Trybunałem Karnym - uwagi dotyczace sprawy Thomasa Lubangi Dyilo, w: Międzynarodowe i europejskie prawo karne - osiagnięcia, kierunki rozwoju, wyzwania, red. J. Nowakowska-Małusecka, I. Topa, Katowice 2015, s. 152-174.

26 K. Stasiak, Prace Komisji Prawa Międzynarodowego nad zbrodniami przeciwko ludzkości a możliwe implikacje dla odpowiedzialności karnej jednostek, w: Odpowiedzialność międzynarodowa w związu z naruszeniami praw człowieka i międzynarodowego prawa humanitarnego, red. M. Balcerzak, J. Kapelańska-Pręgowska, Torun 2016, s. 341-364. 
Kolejny nurt badawczy K. Stasiak obejmował zagadnienia wewnętrznego systemu sprawiedliwości Organizacji Narodów Zjednoczonych. Poświęciła temu zarówno napisany wspólnie z Anną Szarek-Zwijacz artykuł The United Nations Internal Dispute Resolution System After the Reform the Real Chance for Justice? ${ }^{27}$ uwzględniający problemy odpowiedzialności funkcjonariuszy organizacji międzynarodowych, w tym tzw. sygnalistów (whistleblowers), jak i kolejne - Wewnętrzny system sprawiedliwości ONZ i jego doświadczenia w funkcjonowaniu po reformie z $2009 r{ }^{28}$ oraz Odpowiedzialność dyscyplinarna funkcjonariuszy $O N Z^{29}$. W pracach tych przedstawiła przyczyny przeprowadzenia w 2006 r. fundamentalnych zmian wewnętrznego systemu sprawiedliwości ONZ oraz ocenę funkcjonowania nowego modelu w latach 2006-2015. Zwróciła uwagę na potrzebę dalszego doprecyzowania relacji między administracją ONZ a trybunałami ONZ lub innymi organami sprawiedliwości, aby nie istniały wątpliwości, czy wszyscy funkcjonariusze ONZ, łącznie z Sekretarzem Generalnym, podlegają wymiarowi sprawiedliwości ONZ. W zakresie odpowiedzialności dyscyplinarnej funkcjonariuszy zauważyła ponadto, że niestety większość istotnych dla postępowania dyscyplinarnego uregulowań zawarto w instrukcjach administracyjnych Sekretarza Generalnego ONZ, w imieniu którego podejmuje się większość decyzji w toku postępowania. Pomimo istniejącej możliwości przeprowadzenia kontroli sądowej tych decyzji, trybunały ONZ nie oceniają jednakże merytorycznej zasadności decyzji i uregulowań proceduralnych, a jedynie proporcjonalność nałożonych sankcji i zagwarantowanie w postępowaniu prawa do sprawiedliwego procesu. Częściowo jedynie zatem zapewniona jest równość stron postępowania.

Kinga Stasiak podejmowała także inne zagadnienia z zakresu prawa międzynarodowego. Pociągała ją problematyka praw człowieka, co spowodowało przygotowanie wraz z Delaine R. Swensonem i A. Szarek opracowania Poland and the European Court of Human Rights: Selected Issues

${ }^{27}$ K. Stasiak, A. Szarek-Zwijacz, The United Nations Internal Dispute Resolution System After the Reform - the Real Chance for Justice?, w: New Challenges for International Organizations, red. J. Nowakowska-Małusecka, Katowice 2016, s. 177-186.

${ }_{28}$ K. Stasiak, Wewnętrzny system sprawiedliwości ONZ i jego doświadczenia w funkcjonowaniu po reformie z 2009 r., w: System Narodów Zjednoczonych z polskiej perspektywy, red. E. Cała-Wacinkiewicz i in., Warszawa 2017, s. 223-233.

29 K. Stasiak, Odpowiedzialność dyscyplinarna funkcjonariuszy ONZ, Teka Komisji Prawniczej PAN 2017, s. 233-247. 
and Recommendations ${ }^{30}$, poświęconego postępowaniu w sprawach polskich przed Trybunałem Praw Człowieka w Strasburgu. Interesowała się również zagadnieniami stosunków międzypaństwowych, ze szczególnym uwzględnieniem stosunków traktatowych, jak też kwestiami terytorialnymi, co zaowocowało przygotowaniem wraz z A. Szarek-Zwijacz i Wojciechem Szczepanem Staszewskim pracy Stosunki polsko-armeńskie. Wybór dokumentów z wprowadzeniem ${ }^{31}$, jak też sporządzoną wraz z Iryną Kozak i W.Sz. Staszewskim analizą Ewolucja statusu prawnego Kanatu Panamskiego ${ }^{32}$.

Jednym z ostatnich artykułów K. Stasiak był Specjalny Trybunał dla Republiki Środkowoafrykańskiej - nowy typ trybunałów umiędzynarodowionych ?33, świadczący wyraźnie o jej sentymencie dla tematów, którymi otworzyła swoją ścieżkę naukową.

Kinga Stasiak nie ograniczała się do ogłaszania drukiem wyników swoich badań naukowych. Brała bowiem aktywny udział w życiu środowiska osób zainteresowanych prawem międzynarodowym. Wielokrotnie wygłaszała referaty na konferencjach międzynarodowych, krajowych i lokalnych, zawsze wszechstronnie przygotowana i niezwykle komunikatywna ${ }^{34}$; z tożsamym zacięciem brała udział w dyskusjach panelowych ${ }^{35}$.

30 D. Swenson, K. Stasiak, A. Szarek-Zwijacz, Poland and the European Court of Human Rights: Selected Issues and Recommendations, Lublin 2011.

31 K. Stasiak, W.Sz. Staszewski, A. Szarek-Zwijacz, Stosunki polsko-armeńskie. Wybór dokumentów z wprowadzeniem, Lublin 2017.

32 I. Kozak, K. Stasiak, W.Sz. Staszewski, Ewolucja statusu prawnego Kanatu Panamskiego, w: Państwo i terytorium w prawie międzynarodowym, red. J. Menkes, E. Cała-Wacinkiewicz, Warszawa 2015, s. 291-316.

33 K. Stasiak, Specjalny Trybunat dla Republiki Środkowoafrykańskiej - nowy typ trybunatów umiędzynarodowionych?, w: Prawo międzynarodowe. Idee a rzeczywistość, red. E. Cała-Wacinkiewicz, Warszawa 2018, s. 409-419.

$34 \mathrm{~W}$ porządku chronologicznym wymienić należy następujące wystąpienia:

- referat pt. Subject matter jurisdiction of Internationalized Tribunals wygłoszony podczas międzynarodowej szkoły dla doktorantów Marie Curie Top Summer School w Hadze (30 czerwca 2008);

- referat pt. Procedura złożenia skargi i udział Rządu Polskiego w postępowaniu przed Europejskim Trybunałem Praw Człowieka wygłoszony na konferencji organizowanej na WPPKiA KUL (10 czerwca 2011);

- referat pt. Wykonywanie wyroków Europejskiego Trybunału Praw Człowieka i opinie ekspertów wygłoszony na konferencji organizowanej na WPPKiA KUL (10 czerwca 2011);

- referat pt. Zasady dotyczace wyptaty odszkodowań (reparacji) w postępowaniu przed Międzynarodowym Trybunałem Karnym wygłoszony na konferencji organizowanej przez Uniwersytet Śląski w Katowicach (25-26 października 2013); 
Ważnym aspektem pracy naukowej K. Stasiak było przygotowywanie tłumaczeń tekstów źródłowych w postaci dokumentów i orzeczeń międzynarodowych, by uczynić je bardziej dostępnymi szerszemu kręgowi odbiorców. Na łamach Studiów Prawniczych KUL udostępniła tłumaczenia: Protokołu do Afrykańskiej Karty Praw Człowieka i Ludów o Prawach Kobiet w Afryce ${ }^{36}$, Arabskiej Karty Praw Człowieka ${ }^{37}$, Międzynarodowej Konwencji o ochronie praw pracowników migrujących oraz członków ich rodzin $^{38}$, Konwencji o azylu terytorialnym ${ }^{39}$, orzeczenia Trybunału Od-

- referat (wspólnie z dr A. Szarek-Zwijacz) pt. Jurysdykcja sądowa w sprawach funkcjonariuszy ONZ wygłoszony na Zjeździe Katedr Prawa Międzynarodowego Publicznego i Prawa Europejskiego organizowanym przez Uniwersytet Śląski (14-16 maja 2014);

- referat pt. Podjęcie prac nad tematem zbrodni przeciwko ludzkości przez Komisję Prawa Międzynarodowego ONZ - możliwe implikacje dla odpowiedzialności karnej jednostek wygłoszony na VII Warszawsko-toruńskim kolokwium naukowym praw człowieka i międzynarodowego prawa humanitarnego organizowanym przez Uniwersytet Mikołaja Kopernika w Toruniu (5 grudnia 2014);

- referat pt. Due process w postępowaniach w ramach wewnętrznego systemu sprawiedliwości ONZ wygłoszony na konferencji organizowanej przez Polską Grupę Stowarzyszenie Prawa Międzynarodowego przy współudziale Wydziału Prawa i Administracji UMCS (13-14 października 2016);

- referat pt. Budowanie pokoju w Republice Środkowoafrykańskiej - mechanizmy tranzytywnej sprawiedliwości wygłoszony na Zjeździe Katedr i Zakładów Prawa Międzynarodowego organizowanym przez Uniwersytet Szczeciński (17-19 maja 2017);

- referat pt. Sytuacja Ukrainy w świetle postępowania przed Międzynarodowym Trybunałem Karnym wygłoszony na konferencji organizowanej przez Instytut Nauk Politycznych i Spraw Międzynarodowych WNS (Katedra Studiów Wschodnich) oraz Instytut Prawa (Katedra Prawa Międzynarodowego i Amerykańskiego) KUL, Fundację Konrada Adenauera w Polsce oraz Towarzystwo Nauki i Kultury „Libra” (16 stycznia 2018).

35 Odnotowania wymaga udział w dyskusji panelowej pt. The Rule of Law around the World na temat Special Court for Sierra Leone and the Truth and Reconciliation Commission lesson learned, zorganizowanej na WPPKiA KUL (8 grudnia 2012).

36 Protokót do Afrykańskiej Karty Praw Człowieka i Ludów o Prawach Kobiet w Afryce (Protocol to the African Charter on Human and People's Rights of Women in Africa), przyjęty w Maputo dnia 11 lipca 2003 r., tłum. K. Stasiak, Studia Prawnicze KUL 2007, nr 1, s. 137-150.

37 Arabska Karta Praw Człowieka (Arab Charter on Human Rights), przyjęta w Tunisie dnia 22 maja 2004 r., tłum. K. Stasiak, Studia Prawnicze KUL 2007, nr 1, s. 151-166.

38 Międzynarodowa Konwencja o ochronie praw pracowników migrujących oraz członków ich rodzin (International Convention on the protection of the rights of all migrant workers and members of their family), przyjęta w Nowym Jorku dnia 18 grudnia 1990 r., tłum. K. Stasiak, Studia Prawnicze KUL 2007, nr 2-3, s. 139-174.

39 Konwencja o azylu terytorialnym (Convention on territorial asylum), przyjęta $w$ Caracas dnia 28 marca 1954 roku, tłum. K. Stasiak, Studia Prawnicze KUL 2008, nr 2-3, s. 153-156. 
woławczego Organizacji Narodów Zjednoczonych nr 2014-UNAT-457 w sprawie Wasserstrom przeciwko Sekretarzowi Generalnemu ONZ ${ }^{40}$. Biegłość językowa pozwalała jej ponadto na uczestnictwo w konferencjach międzynarodowych w charakterze tłumacza.

Kinga Stasiak była miłośnikiem języka angielskiego, muzyki, narciarstwa, tenisa ziemnego i stołowego ${ }^{41}$. Była wyjątkowo ciepłą, pracowitą, obowiązkową i wszechstronną osobą. Każdy, kto spotkał ją na swojej drodze, może potwierdzić, że zawsze była chętna do pomocy, podchodziła z szacunkiem i życzliwością do ludzi. Świadomość ta pozostanie żywa na Wydziale Prawa, Prawa Kanonicznego i Administracji KUL, któremu K. Stasiak oddała niemal połowę swojego życia.

\section{Wykaz publikacji Kingi Cecylii Stasiak ${ }^{42}$}

Stasiak K., Warunki dopuszczalności interwencji humanitarnej, w: Prawo międzynarodowe publiczne, red. A. Przyborowska-Klimczak, W.Sz. Staszewski, Lublin 2006.

Stasiak K., Specjalne Panele Sędziów w Timorze Wschodnim - jako przyktad trybunatu umiędzynarodowionego, w: Prawo międzynarodowe. Księga pamiątkowa prof. Renaty Szafarz, red. J. Menkes, Warszawa 2007.

Stasiak K., [rec.:] Robert Grzeszczak, Parlamenty państw członkowskich w Unii Europejskiej, Wydawnictwo Uniwersytetu Wroctawskiego, Wroctaw 2004, ss. 256, Studia Prawnicze KUL 2007, nr 1.

Leksykon obywatela, red. S. Serafin, B. Szulik, wstęp J. Kochanowski, Warszawa 2008; autorstwo haseł: Agresja, Cieśniny międzynarodowe, Cudzoziemcy, Interwencja humanitarna, Jeńcy wojenni, Kanały międzynarodowe, Komisje badawcze, Koncyliacja, Konflikt zbrojny, Liga Państw Arabskich, Mediacje, Międzynarodowe

40 Orzeczenie w sprawie Wasserstrom v. Sekretarz Generalny ONZ, tłum. K. Stasiak, Studia Prawnicze KUL 2016, nr 4, s. 175-198.

41 Akta w Archiwum Uniwersyteckim KUL nr 76322 oraz A-4504.

42 Sporządzony na podstawie zapisków dr K. Stasiak. Uporządkowany chronologicznie według daty wydania. 
prawo humanitarne, Naturalizacja, Obywatelstwo, Organizacja Państw Amerykańskich, Przestrzeń kosmiczna, Przestrzeń powietrzna, Repatriacja, Rozbrojenie, Statek powietrzny, Unia Afrykańska, Zbrodnie międzynarodowe.

Encyklopedia Katolicka, t. 12, red. E. Ziemann, Lublin 2008; autorstwo haseł: Mniejszości narodowe. 2. Aspekt prawny, Mniejszości religijne. 2. Aspekt prawny.

Swenson D., Stasiak K., Szarek-Zwijacz A., Poland and the European Court of Human Rights: Selected Issues and Recommendations, Lublin 2011.

Stasiak K., Wystapienia końcowe w sprawie Thomasa Lubangi Dyilo przed Międzynarodowym Trybunałem Karnym (25-26 sierpnia 2011 r., Haga), Studia Prawnicze KUL 2012, nr 1.

Stasiak K., Trybunaty umiędzynarodowione w systemie międzynarodowego sądownictwa karnego, Lublin 2012.

Leksykon prawa międzynarodowego publicznego. 100 podstawowych pojęć, red. A. Przyborowska-Klimczak, D. Pyć, Warszawa 2012; autorstwo haseł: Agresja, Azyl, Bezpieczeństwo międzynarodowe, Dyskryminacja, Jurysdykcja, Okupacja, Operacje pokojowe, Prawo narodów do samostanowienia, Rozbrojenie i ograniczenie zbrojeń, Odszkodowania wojenne (współautor A. Szarek).

Stasiak K., The Position of Defence Counsel before the International Criminal Court a Few Comments on the Lubanga Case, Review of Comparative Law 2012, t. 17.

Potrzeszcz J., Stasiak K., Mortui vivos docent. In Memory of Rev. Prof. Antoni Kość, SVD, Review of Comparative Law 2012, t. 17.

Stasiak K., ICTY Prosecutor Serge Brammertz, International Criminal Justice: Lessons Learned, Future Challenges Supranational Criminal Law Lecture Series. Haga, 12 września 2012 r., Studia Prawnicze KUL 2013, nr 1.

Leksykon administratywisty, red. S. Wrzosek, A. Haładyj, M. Domagała, Radom 2013; autorstwo haseł: Cudzoziemiec, Konflikt zbrojny, Mniejszości narodowe, Odpowiedzialność międzynarodowa, Przestrzeń powietrzna i kosmiczna, Uchodźca.

Stasiak K., Wspótpraca Organizacji Narodów Zjednoczonych z Prokuratorem Międzynarodowego Trybunatu Karnego, w: Prawo organizacji międzynarodowych wobec problemów wspótczesnego świata. Księga Jubileuszowa dedykowana Pani Profesor Genowefie Grabowskiej, red. B. Mikołajczyk, J. Nowakowska-Małusecka, Bydgoszcz-Katowice 2014.

Stasiak K., Zasady dotyczace naprawienia szkody pokrzywdzonym w postepowaniu przed Międzynarodowym Trybunałem Karnym - uwagi dotyczace sprawy Thomasa Lubangi Dyilo, w: Międzynarodowe i europejskie prawo karne - osiagnięcia, kierunki rozwoju, wyzwania, red. J. Nowakowska-Małusecka, I. Topa, Katowice 2015.

Kozak I., Stasiak K., Staszewski W.Sz., Ewolucja statusu prawnego Kanatu Panamskiego, w: Państwo i terytorium w prawie międzynarodowym, red. J. Menkes, E. Cała-Wacinkiewicz, Warszawa 2015. 
Stasiak K., Szarek-Zwijacz A., The United Nations Internal Dispute Resolution System After the Reform - the Real Chance for Justice?, w: New Challenges for International Organizations, red. J. Nowakowska-Małusecka, Katowice 2016.

Stasiak K., Prace Komisji Prawa Międzynarodowego nad zbrodniami przeciwko ludzkości a możliwe implikacje dla odpowiedzialności karnej jednostek, w: Odpowiedzialność międzynarodowa w związku z naruszeniami praw człowieka i międzynarodowego prawa humanitarnego, red. M. Balcerzak, J. Kapelańska-Pręgowska, Toruń 2016.

Stasiak K., Wewnętrzny system sprawiedliwości ONZ i jego doświadczenia w funkcjonowaniu po reformie z 2009 r., w: System Narodów Zjednoczonych z polskiej perspektywy, red. E. Cała-Wacinkiewicz i in., Warszawa 2017.

Stasiak K., Odpowiedzialność dyscyplinarna funkcjonariuszy ONZ, Teka Komisji Prawniczej PAN 2017.

Stasiak K., Staszewski W.Sz., Szarek-Zwijacz A., Stosunki polsko-armeńskie. Wybór dokumentów z wprowadzeniem, Lublin 2017.

Stasiak K., Specjalny Trybunat dla Republiki Środkowoafrykańskiej - nowy typ trybunatów umiędzynarodowionych?, w: Prawo międzynarodowe. Idee a rzeczywistość, red. E. Cała-Wacinkiewicz, Warszawa 2018.

\section{Wykaz tłumaczeń sporządzonych przez Kingę Cecylię Stasiak ${ }^{43}$}

Protokót do Afrykańskiej Karty Praw Człowieka i Ludów o Prawach Kobiet w Afryce (Protocol to the African Charter on Human and People's Rights of Women in Africa), przyjęty w Maputo dnia 11 lipca 2003 r., tłum. K. Stasiak, Studia Prawnicze KUL 2007, nr 1.

Arabska Karta Praw Człowieka (Arab Charter on Human Rights), przyjęta w Tunisie dnia 22 maja 2004 r., tłum. K. Stasiak, Studia Prawnicze KUL 2007, nr 1.

Międzynarodowa Konwencja o ochronie praw pracowników migrujących oraz członków ich rodzin (International Convention on the protection of the rights of all migrant workers and members of their family), przyjęta w Nowym Jorku dnia 18 grudnia 1990 r., tłum. K. Stasiak, Studia Prawnicze KUL 2007, nr 2-3.

Konwencja o azylu terytorialnym (Convention on territorial asylum), przyjęta w Caracas dnia 28 marca 1954 roku, tłum. K. Stasiak, Studia Prawnicze KUL 2008, nr 2-3.

43 Sporządzony na podstawie zapisków dr K. Stasiak. Uporządkowany chronologicznie według daty wydania. 
Acknowledgements for the 40th jubilee of rev. Professor Henryk Misztal's scholarly and didactical work, tłum. K. Stasiak, M. Rzeszót, w: Ks. Henryk Misztal, Duc in altum. Sprawy kanonizacyjne. Wybór pism, red. L. Fiejdasz, Lublin 2009.

Orzeczenie w sprawie Wasserstrom v. Sekretarz Generalny ONZ, tłum. K. Stasiak, Studia Prawnicze KUL 2016, nr 4.

\section{Tematy pracy magisterskich przygotowanych na seminariach prowadzonych przez dr Kingę Stasiak ${ }^{44}$}

Activities of states in Outer Space in light of international law and states' practice.

Czynności notarialne konsula.

Dyplomatyczne sposoby rozstrzygania sporów międzynarodowych.

Europejski Nakaz Aresztowania.

Funkcje konsularne.

Grupa Wyszehradzka.

Immunitet jurysdykcyjny członków misji dyplomatycznych i urzędów konsularnych.

Instytucja ekstradycji w świetle prawa międzynarodowego i polskiego.

Instytucja obywatelstwa w świetle prawa międzynarodowego i polskiego.

Jurysdykcja Międzynarodowego Trybunatu Karnego.

Kompetencje głowy państwa w zakresie stosunków międzynarodowych i prawa międzynarodowego.

Konferencje międzynarodowe jako forma wspótpracy państw.

Legalność interwencji NATO w Kosowie.

Międzynarodowy Trybunał Karny dla byłej Jugosławii.

Ochrona dziedzictwa kulturowego w czasie pokoju w świetle dokumentów UNESCO.

Ochrona inwestorów w prawie międzynarodowym na podstawie dwustronnych umów o popieraniu i wzajemnej ochronie inwestycji.

Ochrona ludności cywilnej w niemiędzynarodowych konfliktach zbrojnych.

Ochrona podwodnego dziedzictwa kulturalnego w prawie międzynarodowym.

Ochrona praw dziecka w systemie Organizacji Narodów Zjednoczonych.

Ochrona praw kobiet w Radzie Europy i Lidze Państw Arabskich.

Ochrona prawa własności w orzecznictwie Europejskiego Trybunału Praw Człowieka.

Ochrona uzupetniająca i pobyt tolerowany w świetle prawa międzynarodowego i polskiego.

Odpowiedzialność osób fizycznych za zbrodnie terroryzmu przed międzynarodowymi trybunałami karnymi.

Odpowiedzialność państw za działalność w przestrzeni kosmicznej.

${ }^{44}$ Opracowano na podstawie dokumentacji studiów w KUL. 
Ograniczenia metod i środków walki w konfliktach zbrojnych.

Organizacja Paktu Pótnocnoatlantyckiego.

Państwa upadte w prawie międzynarodowym.

Prawnomiędzynarodowe aspekty użycia broni masowego rażenia.

Prawnomiędzynarodowe wyjątki od zakazu użycia sity a zwalczanie terroryzmu międzynarodowego.

Prawo do poszanowania życia rodzinnego uchodźców w prawie międzynarodowym i polskim.

Problem dzieci-żotnierzy w prawie międzynarodowym.

Przeciwdziatanie i zwalczanie terroryzmu lotniczego w prawie międzynarodowym.

Przeciwdziałanie zmianom klimatu w prawie międzynarodowym.

Przywileje i immunitety członków misji dyplomatycznych.

Przywileje i immunitety konsularne.

Rozbrojenie w zakresie broni chemicznej w świetle prawa międzynarodowego.

Staty Trybunat Arbitrażowy.

State responsibility for cyberattacks in International Law.

Status jeńca wojennego w prawie międzynarodowym na tle wybranych współczesnych konfliktów zbrojnych.

Status jeńców wojennych w prawie międzynarodowym.

Status morza otwartego w prawie międzynarodowym.

Status obszarów polarnych w świetle prawa międzynarodowego.

Status prawnomiędzynarodowy Francji.

Status uchodźcy w świetle prawa międzynarodowego.

Stosunki traktatowe między Rzecząospolita Polska a Republikg Federalna Niemiec po 1990 roku.

Udział Organizacji Narodów Zjednoczonych w przeciwdziałaniu i zwalczaniu terroryzmu.

Udzielanie statusu uchodźcy w prawie międzynarodowym i prawie polskim.

Unikanie podwójnego opodatkowania w świetle umów międzynarodowych.

Uznanie państwa w świetle prawa międzynarodowego.

Walka z terroryzmem a zakaz tortur w systemie ochrony praw człowieka Rady Europy.

Wolność sumienia $i$ wyznania w świetle Konwencji o ochronie praw człowieka i podstawowych wolności.

Zakaz tortur oraz innego okrutnego, nieludzkiego lub poniżającego traktowania lub karania w systemie Rady Europy.

Zapobieganie i zwalczanie handlu narkotykami w ramach Organizacji Narodów Zjednoczonych i Unii Europejskiej.

Zasady ekstradycyjne w świetle prawa międzynarodowego.

Zbrodnie wojenne w statutach Międzynarodowego Trybunatu Karnego i trybunałów ad hoc.

Zwalczanie handlu ludźmi w dokumentach Organizacji Narodów Zjednoczonych $i$ Rady Europy.

Zwalczanie i zapobieganie korupcji w prawie międzynarodowym. 


\section{Bibliografia}

Kuźniar-Kwiatek D., [rec.:] Kinga Stasiak, Trybunały umiędzynarodowione w systemie międzynarodowego sadownictwa karnego, Wydawnictwo KUL, Lublin 2012, s. 324, Studia Prawnicze KUL 2013, nr 1.

Staszewski W.Sz., Szarek-Zwijacz A., In memoriam. Kinga Cecylia Stasiak. 1981-2019, Studia Prawnicze 2019, nr 2.

s.v. Stasiak Kinga, w: Encyklopedia 100-lecia KUL, t. 2, red. E. Gigilewicz, Lublin 2018.

\section{Streszczenie}

Artykuł stanowi wspomnienie i prezentację życia i dorobku śp. dr Kingi Stasiak (1981-2019), przedwcześnie zmarłej znakomitej badaczki prawa międzynarodowego publicznego. Ukazuje jej drogę zawodową, związaną z Katolickim Uniwersytetem Lubelskim Jana Pawła II, rozwój zainteresowań badawczych oraz zaangażowanie na rozmaitych polach aktywności naukowej, dydaktycznej i osobistej. Zwraca uwagę, że dorobek naukowy K. Stasiak poza monografią Trybunaty umiędzynarodowione w systemie międzynarodowego sądownictwa karnego (Lublin 2012) obejmuje czternaście artykułów naukowych opublikowanych w czasopismach naukowych i pracach zbiorowych, pięć tłumaczeń tekstów źródłowych oraz trzy drobne wypowiedzi naukowe, jak też liczne hasła encyklopedyczne.

Artykuł przedstawia główne pola badawczych dociekań K. Stasiak, poczynając od umiędzynarodowionych trybunałów karnych, zakresu ich kompetencji, przebiegu postępowania oraz znaczenia na arenie międzynarodowej. Jako kolejne obszary badań wskazuje warunki dopuszczalności interwencji humanitarnej, międzynarodowe prawo karne, ze szczególnym uwzględnieniem norm prawa międzynarodowego określających materialnoprawne i proceduralne aspekty odpowiedzialności za zbrodnie wojenne, przeciwko pokojowi i przeciwko ludzkości, zagadnienia wewnętrznego systemu sprawiedliwości Organizacji Narodów Zjednoczonych, praw człowieka. Podkreśla wysoką kulturę słowa i sposób posługiwania się językiem prawniczym oraz odpowiedzialność za formułowane tezy, udowadniane zarówno przy okazji mniejszych, jak i bardziej rozbudowanych opracowań.

Artykuł akcentuje nadzwyczajne zaangażowanie dydaktyczne dr K. Stasiak, szeroką aktywność konferencyjną i translatorską oraz ofiarną służbę na rzecz macierzystej Uczelni. Nie zapomniano o tym, że była wyjątkowo ciepłą, pracowitą, obowiązkową i wszechstronną osobą, a każdy, kto spotkał ją na swojej drodze, może potwierdzić, że zawsze była chętna do pomocy, podchodziła z szacunkiem i życzliwością do ludzi.

Słowa kluczowe: dr Kinga Stasiak, prawo publiczne międzynarodowe, umiędzynarodowione trybunały, prawa człowieka 


\section{KINGA CECYLIA STASIAK (1981-2019)}

\section{Sum ma ry}

This article commemorates the life and writings of Dr Kinga Stasiak (1981-2019), the prematurely deceased eminent scholar of public international law. It discusses her career path, associated with The John Paul II Catholic University of Lublin, the formation and development of her research interests and involvement in the various fields of research, teaching, and personal activities. It highlights the fact that K. Stasiak's academic achievement, apart from the monograph Trybunaty umiędzynarodowione w systemie międzynarodowego sądownictwa karnego [Internationalized tribunals in the system of international criminal courts] (Lublin 2012), includes fourteen articles published in journals and collaborative works, five translations of source texts, and three small academic forms, as well as numerous encyclopaedic entries.

The article discusses the main areas of K. Stasiak's inquiry, beginning with internationalized criminal tribunals, their scope of competence, the course of the proceedings before them, and their importance in the international arena. Additional fields include conditions for the permissibility of a humanitarian intervention, as well as international criminal law with special emphasis on the norms of international law defining the substantive and procedural aspects of liability for war crimes, crimes against peace and humanity, matters relating to the United Nation's internal justice system, and human rights. It emphasizes her impeccable use of the written word and legal language, as well as an attitude of responsibility for theses formulated equally in her brief works as in more complex publications.

The article emphasizes Dr K. Stasiak's extraordinary commitment to teaching, extensive conference participation and translation activities, as well as her self-sacrificing service to the Alma Mater. Nor can one forget her exceptional warmth as a person, diligence, and sense of duty, as well as broad horizons and open mind. Anyone who ever met Dr K. Stasiak will readily confirm that she was always there to help and treated others with respect and kindness.

Key words: dr Kinga Stasiak, public international law, internationalized tribunals, human rights

\section{КИНГА ЦЕЦИЛИЯ СТАСЯК (1981-2019)}

\section{Резюме}

Статья представляет собой воспоминание, представляющее жизнь и достижения преждевременно умершей Кинги Стасяк (1981-2019), кандидата наук, выдающейся исследовательницы международного публичного права. 
В статье показан ее профессиональный путь, связанный с Люблинским католическим университетом Иоанна Павла II, развитие исследовательских интересов и участие в различных областях деятельности: научной, дидактической и личной. Указывается, что научные достижения К. Стасяк, кроме монографии Трибуналы, интернационализированные в системе международного уголовного правосудия (Люблин, 2012), включают четырнадцать научных статей, опубликованных в научных журналах и коллективных трудах, пять переводов исходных текстов и три небольших научных высказывания, а также многочисленные энциклопедические статьи.

В статье представлены основные направления исследований К. Стасяк, начиная с интернационализированных уголовных трибуналов, объема их компетенций, хода производства и их значения на международной арене. В качестве дальнейших направлений исследований указываются условия допустимости гуманитарного вмешательства, международное уголовное право, особое внимание уделяется нормам международного права, определяющим материально-правовые и процессуальные аспекты ответственности за военные преступления против мира и человечности, рассматриваются вопросы внутренней системы правосудия Организации Объединенных Наций и права человека. Подчеркивается высокая культура слова ученой и способ использования юридического языка, а также ответственность за сформулированные тезисы, подтвержденные как в случае небольших, так и более объемных исследований.

В статье подчеркивается выдающаяся дидактическая приверженность кандидата наук К. Стасяк, многократное участие в научных конференциях и переводческая деятельность, а также преданное служение своему университету. Не забыто о том, что она была исключительно сердечным, трудолюбивым, ответственным и разносторонним человеком, и каждый, кто встречал ее на своем пути, может подтвердить, что она всегда была готова помочь, относилась к людям с уважением и добротой.

Ключевые слова: кандидат наук Кинга Стасяк, международное публичное право, интернационализированные трибуналы, права человека 
